\title{
Comparative Score 0
}

National Cancer Institute

\section{Source}

National Cancer Institute. Comparative Score 0. NCI Thesaurus. Code C126681.

A score of 0 on a comparative scale that ranges from 3+: Very much better to -3: Very much worse. 